\title{
Studies on the Route and Time of Injection of Donor Cells for the Induction of Acquired Tolerance in the Skin Homotransplantation in Mice
}

\author{
By
}

\author{
Yoshinobu Ishikawa, Sakari Sato, Shingo Kakizaki \\ (石川義信) (佐藤涡) (柿崎真吾) \\ and Jin Takita \\ (滰田仁) \\ From the Surgical Clinic of Prof. S-T. Katsura \\ Tohoku University School of Medicine, Sendai
}

(Received for publication, April 14, 1959)

Based on the concept of acquired tolerance ${ }^{11}$, several experiments were conducted on the skin homotransplantation in mice. In the present paper, some new findings concerning the effective route and time through which and at which donor cells were given will be described.

\section{EXPERIMENTAL}

Materials and methods

1) Donor and recipient; Adult mice of inbred C57BL/6Ms strain were employed as the donor and the mice of uniform dd-strain were used as the recipient.

2) Skin homotransplantation; 25 to $85 \mathrm{~mm}^{2}$. of the grafts of free full thickness skin were excised out from the back or both sides of breast of the donor, and each graft was transplanted in the fitted style into the back of the recipient animal by the non-suture method reported in our previous paper's).

3) Collection of whole blood; A tail of $\mathrm{C} 57 \mathrm{BL} / 6 \mathrm{Ms}$ mouse was warmed by hot water (about $40^{\circ} \mathrm{C}$ ) and cut off, the bleeding blood was absorbed into the syringe containing 10 per cent solution of sodium citrate.

4) Preparation of spleen cell suspension; After incision at the upper abdominal region and ligation of the vessels at splenic portal of C57BL/ $6 \mathrm{Ms}$ mice, the spleen was extirpated aseptically under non-anaesthetic condition. Adipose tissue adhered to the surface was removed and then the spleen was compressed carefully in a mortar and suspended in each approximately $0.2 \mathrm{ml}$. of physiological saline solution. 
5) Evaluation of results; Whether the graft which had been homotransplanted was still surviving or not was determined according to the findings obtained by macroscopical examinations and palpation and also to the histological findings.

\section{Results}

I. Effects of subcutaneous injections of whole blood or spleen cell suspensions on the homotransplantability

1) Control experiments (Group A) :-Seventeen mice of uniform ddstrain were injected subcutaneously on their backs with each $0.06 \mathrm{ml}$. of physiological saline solution and then the grafts obtained from C57BL/ $6 \mathrm{Ms}$ mice were transplanted 3 or 4 weeks after birth as described above.

As shown in Table I, homografts were sloughed from more than half of the experimental animals in the second week after the transplantation,

TABLE I

Survival Period of the Homografts in Control Experiment (Group A). 17 mice were used

\begin{tabular}{l|c|c|c}
\hline Time after the transplantation (week) & 2 & 5 & 10 \\
\hline No. of animals with surviving graft & 8 & $1^{*}$ & 0 \\
& $(47.1 \%)$ & $(5.8 \%)$ & $(0)$
\end{tabular}

* One graft survived until the 7 th week. Average survival period of the homografts was 24.4 days.

and only in one case the graft survived until the seventh week. The average survival period was 24.4 days. Growing of the black hair inherent in the donor could not be observed in any one of this group.

2) Effect of subcutaneous injection of the whole blood of the prospective donor; Fifty-four mice of dd-strain 8 to 24 hours after birth were injected subcutaneously on their backs with each $0.06 \mathrm{ml}$. of the whole blood obtained from adult mice of C57BL/6Ms strain. Then 3 or 4 weeks after birth these animals were transplanted with the grafts excised from each animal from which whole blood had been collected.

Results are summarized in Table II. Of these 54 animals, homografts survived in 50 cases (92.5 per cent), 36 cases (66.6 per cent), 24 cases (44.4 per cent), 18 cases (33.3 per cent), 16 cases (29.6 per cent), and eight cases (14.8 per cent) 4, 9, 19, 29, 39, and 49 weeks after the transplantation respectively. However, in the 53rd week these grafts sloughed in all cases. Besides, the growing of the black hair was also observed from the second week after the transplantation and in the third week this could be seen in 28 cases $(51.8$ per cent of total animals and 56.0 per cent of 
TAB LE II

Survival Period of Homografts in Animals Injected with the Whole Blood of the Prospective Donor.

54 mice were used

\begin{tabular}{c|c|c|c|c|c|c|c}
\hline $\begin{array}{c}\text { Time after the } \\
\text { transplantation } \\
\text { (week) }\end{array}$ & 5 & 10 & 20 & 30 & 40 & 50 & 60 \\
\hline $\begin{array}{c}\text { No. of animals with } \\
\text { surviving graft }\end{array}$ & $\begin{array}{c}50 \\
(92.5 \%)\end{array}$ & $\begin{array}{c}36 \\
(66.6 \%)\end{array}$ & $\begin{array}{c}24 \\
(44.4 \%)\end{array}$ & $\begin{array}{c}18 \\
(33.3 \%)\end{array}$ & $\begin{array}{c}16 \\
(29.6 \%)\end{array}$ & $\begin{array}{c}8 \% \\
(14.8 \%)\end{array}$ & 0 \\
\hline
\end{tabular}

* Of these, 4 grafts survived until the 53rd week.

animals with surviving grafts). After the fourth week, however, the percentage gradually decreased and no case was found in the 40th week.

3) Effect of subcutaneous injection of the spleen cell suspensions of the prospective donor (Group B): In this experiment 39 mice were employed. Each one fifth to one fourth of the total volume of the spleen cell suspension obtained from one individual was injected subcutaneously on the back of recipient animal instead of the whole blood.

Table III represents these results. In most of the animals, grafts were absorbed and sloughed until the 35 th week after transplantation and in one case it survived even after the 45 th week. Growing of black hair

\section{TABLE III}

Survival Period of Homografts in Animals Injected with the Spleen Cell Suspensions of the Prospective

Donor (Group B). 39 mice were used

\begin{tabular}{l|c|c|c|c|c|c}
\hline $\begin{array}{c}\text { Time after the transplan- } \\
\text { tation (week) }\end{array}$ & 5 & 10 & 20 & 30 & 40 & 50 \\
\hline $\begin{array}{l}\text { No. of animals with survi- } \\
\text { ving graft }\end{array}$ & $\begin{array}{c}32 \\
(82.0 \%)\end{array}$ & $\begin{array}{c}27 \\
(69.2 \%)\end{array}$ & $\begin{array}{c}14 \\
(35.8 \%)\end{array}$ & $\begin{array}{c}5 * \\
(12.8 \%)\end{array}$ & $(2.5 \%)$ & $1 * *$ \\
$*$ Of these, 4 grafts sloughed gradually until the 35th week. \\
$* *$ One graft survived until the 45th week.
\end{tabular}

was also observed from the second week in some of the grafts and in the fifth week 30.7 per cent of the total animals of this group (12 cases) and 37.5 per cent of animals with surviving grafts had black hair in the grafts. II. Effect of time of injection on the homotransplantatability

1) Group $\mathrm{C}$ :- - Twenty-one mice of dd-strain 16 to 18 days after birth were injected subcutaneously with each one third of the spleen cell suspension obtained from one individual of $\mathrm{C} 57 \mathrm{BL} / 6 \mathrm{Ms}$ strain, and on the 30th day after birth they were transplanted with each graft excised from the animal from which the spleen cell suspension was prepared. 
As summarised in Table IV, homografts could survive until the fifth week in nine cases (42.8 per cent), and only in one case (4.7 per cent) it survived even until the 10 th week. However, in the 14 th week these grafts sloughed in all cases.

TA B LE IV

Comparison of Survival Period of Homografts Transplanted after the Different Time of Injection of Spleen Celle Suspensions with or without X-Irradiation

\begin{tabular}{|c|c|c|c|c|}
\hline & \multirow{2}{*}{ Treatment } & \multicolumn{3}{|c|}{ No. of animals with surviving graft } \\
\hline & & 5th week & 10th week & 20 th week \\
\hline $\begin{array}{l}\text { Group } C \\
21 \text { mice }\end{array}$ & $\begin{array}{l}\text { Spleen cell suspension was injected } \\
\text { on } 16 \text { th-18th day. }\end{array}$ & $\begin{array}{c}9 \\
(42.8 \%)\end{array}$ & $(4.7 \%)$ & 0 \\
\hline $\begin{array}{l}\text { Group D } \\
36 \text { mice }\end{array}$ & $\begin{array}{l}\text { X-irradiated every other day for } 3 \\
\text { times from } 2 \text { days after birth. }\end{array}$ & $\begin{array}{c}9 \\
(25.0 \%)\end{array}$ & 0 & \\
\hline $\begin{array}{l}\text { Group E } \\
26 \text { mice }\end{array}$ & $\begin{array}{l}\text { X-irradiated every other day for } 3 \\
\text { times from } 2 \text { days after birth and } \\
\text { spleen cell suspension was injected } \\
\text { on } 16 \text { th day. }\end{array}$ & $\begin{array}{c}23 \\
(88.4 \%)\end{array}$ & $(61.5 \%)$ & $\begin{array}{c}7 \\
(26.9 \%)\end{array}$ \\
\hline $\begin{array}{l}\text { Group F } \\
23 \text { mice }\end{array}$ & $\begin{array}{l}\text { X-irradiated every other day for } 3 \\
\text { times from } 2 \text { weeks after birth and } \\
\text { spleen cell suspension was injected } \\
\text { on the } 3 \text { rd week. }\end{array}$ & $\begin{array}{c}14 \\
(60.8 \%)\end{array}$ & $\begin{array}{c}8 \\
(34.7 \%)\end{array}$ & $(18.6 \%)$ \\
\hline
\end{tabular}

2) Group D:-Thirty-six mice of dd-strain were used. From the second day after birth animals were irradiated with $100 \mathrm{r}$ of X-ray $(150 \mathrm{kv}$, $40 \mathrm{~cm}$., $\mathrm{Cu} 0.5 \mathrm{~mm}$., Al p.5 mm.) every other day three times. Then on the 32nd day after birth homotransplantations were performed with the grafts obtained from C57BL/6Ms mice.

In this group grafts, as shown Table IV, survived until the fifth week in nine cases (25.0 per cent), however, any of them could not survive until the 10 th week after the transplantation.

3) Group E:-Twenty-six mice of dd-strain were irradiated with $100 \mathrm{r}$ of X-ray $(150 \mathrm{kv}, 40 \mathrm{~cm}$., Cu $0.5 \mathrm{~mm}$., Al $0.5 \mathrm{~mm}$.) every other day three times from the second day of birth, and then on the 16th day these animals were injected subcutaneously with one third volume of the spleen cell suspensions obtained from each prospective donor. After these treatments, experimental animals were homotransplanted with each graft obtained from $\mathrm{C} 57 \mathrm{BL} / 6 \mathrm{Ms}$ mice from which spleen cell suspensions were prepared.

As shown in Table IV, grafts were surviving in 25 cases (88.4 per cent), 16 cases ( 61.5 per cent), and seven cases (26.9 per cent) 14,9 , and 
19 weeks after the transplantation respectively. Moreover, growing of the black hair could be observed in six cases $(23.0$ per cent of the total animals and 26.0 per cent of animals with surviving graft) in the fifth week.

4) Group F:-From the second week after birth, 23 mice of ddstrain were irradiated every other day three times with $100 \mathrm{r}$ of X-ray (150 kv, $40 \mathrm{~cm}$., Cu $0.5 \mathrm{~mm}$., $\mathrm{Al} 0.5 \mathrm{~mm}$.), and 2 week after birth spleen cell suspensions were injected suscutaneously as in the cases described above. Then on the 34th day after birth these animals were homotransplanted with the grafts obtained from the C.57BL/6Ms mice from which spleen cell suspensions were prepared.

Surviving grafts were observed in 14 cases (60.8 per cent), eight cases ( 34.7 per cent), and two cases ( 8.6 per cent) on the fifth, 10 th and 20 th week after the transplantation respectively (Table IV).

Survival periods of homotransplanted grafts in these groups described above are compared in Fig. 1. Although, the survival period of the grafts

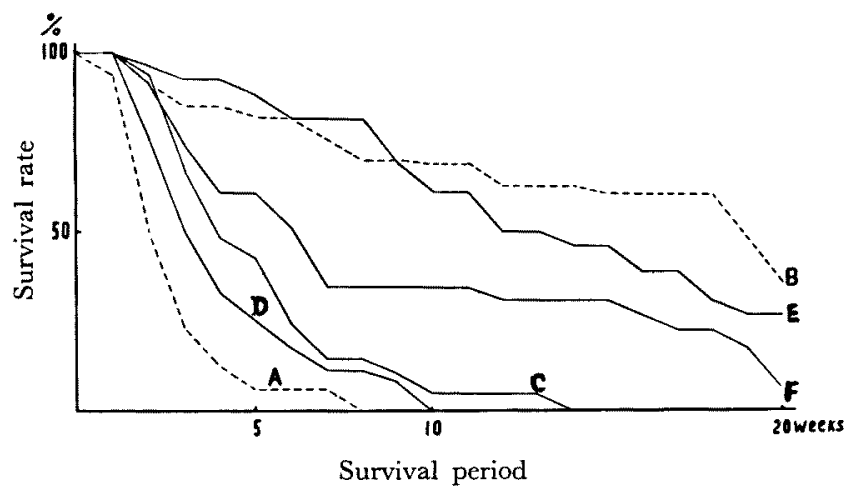

Fig. 1. Comparison of survival period of homografts transplanted after the different time of injection of spleen cell suspension with or without $\mathrm{X}$ irradiation. (see Text)

in Group C (spleen cell suspension was injected 16 to 18 days after birth and homotransplantation was performed on the 30 th day) was considerably shorter than that in Group B (spleen cell suspension was injected 8 to 24 hours after birth and homotransplantation was performed in the fourth to fifth week), this was slightly longer than in the case of Group A (physiological saline solution was injected 8 to 24 hours after birth and homotransplantation was performed in the fourth to fifth week). Thus, there was a significant difference of 37.0 per cent at the level of five per cent between the surviving rates of homografts in Group $\mathrm{C}$ and Group A. From this result the effect of subcutaneous injection of the cells of homologous origin could be recognized even on the 16th to 18th day after birth. 
Besides, in the case of Group $E$ which had been irradiated shortly after birth prior to the injection of the donor cells which was performed on the 16th to 18 th day, the survival period was prolonged almost as much as in Group B. Thus, no significant difference was observed between surviving rates of the homografts in Group $\mathrm{E}$ and Group $\mathrm{F}$ at the level of five per cent.

Next, considerable prolongation of survival period was also observed in Group $\mathrm{F}$ which had been irradiated from two weeks after birth and in the third week the spleen cell suspensions were injected. However, in Group D which was irradiated soon after birth but was not injected with the spleen cell suspension prior to the homotransplantation, little significant prolongation was observed as compared to Group A; in the fifth week no significant difference of surviving rate between both groups was observed at the level of five per cent.

\section{Discussion}

In the case of skin homotransplantation, it is recognized that the route and time of injection of the donor cells which can induce the tolerance into recipient differ depending upon the kind of experimental animals. Thus, Woodruff and Simpson ${ }^{3) 4}$ reported that in the case of rats tolerance could be induced also by the subcutaneous injection of donor cells, and that effective period of time was until about the second week after birth. In the case of mice, however, it was reported by Billingham et al. ${ }^{5 / 6)}$ that such a tolerance could not be induced by the subcutaneous injection of the donor cells, and that effective poeriod of injection was at most seven days after birth.

In the present experiments on the skin homotransplantation with C57BL/6Ms mice as donor and the mice of uniform dd-strain as recipients, we succeeded in the establishment of the transplantation which had been performed in the fourth to fifth week after birth injecting mice subcutaneously either with the whole blood or spleen cell suspensions obtained from the prospective donors 8 to 24 hours after birth. Moreover, the injection of donor cells was slightly effective even on the 16th to 18 th day after birth. However, the tolerance induced by these treatments did not maintain more than 53 weeks after the homotransplantation.

Besides, concerning the prolongaton of the acquired tolerance range the effect of cortisone treatment prior to the injection of donor cells was studied in mice by Woodruff and Simpson ${ }^{4}$, but no significant effect was observed in their experiments.

In the present experiments, the tolerance range was evidently prolonged by X-irradiation which had been performed shortly after birth. However, it remains obscure at the present time whether or not the effect 
of X-irradiation observed here is a phenomenon similar to what resulted from the mechanism of so called radiation chimera ${ }^{7)}$. In our experiments, however, donor cells were given two weeks after the X-irradiation and neither early mortality nor delayed mortality was observed in the recipients. From this fact some other mechanism may be considered as the cause of this phenomenon.

\section{Summary}

1) Skin homotransplantation was performed in the fourth to fifth week after birth of uniform dd-strain mice which had been injected subcutaneously with the whole blood or spleen cell suspension obtained from the prospective donors ( $\mathrm{C} 57 \mathrm{BL} / 6 \mathrm{Ms}$ mice) 8 to 24 hours after birth. It was successful in considerably high percentage. Homografts survived for a long period of time and the growing of black hair inhered in the donor was also observed in many cases.

2) Subcutaneous injection of the cells from homologous origin was effective even after 16 to 18 days after birth.

3) If the recipients were $\mathrm{X}$-irradiated shortly after birth, the tolerance range was prolonged evidently against controls without irradiation.

\section{References}

1) Billingham, R. E., Brent, L. \& Medawer, P. E., Nature, 1953, 172, 603.

2) Sato, S., Kakizaki, S. \& Ishikawa, Y., Tohoku J. Exp. Med., 1958, 67, 359.

3) Woodruff, M.F.A. \& Simpson, L. O., Brit. J. Exp. Path., 1955, 36, 494.

4) Woodruff, M.F.A. \& Simpson, L. O., Ann. N. Y. Acad. Sci., 1957, 64, 792.

5) Billingham, R. E. \& Brent, L., Transpl. Bull., 1957, 4, 67.

6) Billingham, R. E. \& Brent, L., Ann. N. Y. Acad. Sci., 1957, 69, 618.

7) Main, J. M. \& Prehn, R. T., J. Nat. Cancer Inst., 1955, 15, 1023. 